\title{
KAZIMIERZ POCHWALSKI'S SKETCHBOOK OF EASTERN TRAVELS
}

\begin{abstract}
"The picturesque is here in abundance. At every step one sees ready-made pictures, which would bring fame and fortune to twenty generations of painters." (Delacroix, April 2, 1832, Meknes) $)^{1)}$
\end{abstract}

\section{KAZIMIERZ POCHWALSKI}

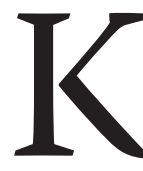

Kazimierz Pochwalski was born into a family with a tradition of three generations of painters, a rarity in Poland. ${ }^{2)}$ He studied painting, of Fine Arts under Władysław Łuszczkiewicz and Felix Szynalewski, and later, from 1876 to 1878, under Jan Matejko. ${ }^{3)}$ He continued his studies at the Munich Academy of Fine Arts with Otto Seitz and Alexander Wagner. Before the Christmas of 1882, Pochwalski went to Paris, where he studied portrait painting in art galleries and museums. ${ }^{4}$ In Paris, his tutor was Leon Bonnat ${ }^{5}$.

Between 1883 and 1892, Pochwalski lived in Krakow. There, in the autumn of 1883, he met Henryk Sienkiewicz, his beloved new friend. During this period, Pochwalski took many trips (to Munich and Vienna, for example)

\footnotetext{
1) Stewart (1971).

2) Micke-Broniarek (2008: 88).

3) http://www.pochwalski.edu.pl/readarticle.php?article_id=51

4) http://www.pochwalski.edu.pl/readarticle.php?article_id=51

5) Blak (2001: 257).
} 
and longer journeys. ${ }^{6)}$ Two Eastern trips, that will be described later, took place between those journeys. In Vienna, he made a contact with the imperial court $^{7)}$ and presented himself to the Emperor Franz Joseph. The Minister of Enlightenment and Art - Baron Paul Gautsch - encouraged Pochwalski to settle in Vienna, where the artist immediately received orders for his paintings, so that a vision of a successful future began to appear before him. The painter moved to Vienna at the beginning of 1892 and lived there until the summer of 1919.8) He worked at the Academy until 1919 and later was awarded the title of 'Honorary Member of the Academy' and 'Professor'. ${ }^{9}$ In 1915, Pochwalski collaborated with Jerzy Mycielski as 'Vice-President of the Organizing Committee of the Polish Art Exhibition in Vienna'. ${ }^{10)}$

In Vienna, his house and studio were visited by: Henryk Sienkiewicz, Kazimierz Chłędowski, Karol Lanckoroński, Tadeusz Rittner and Ignacy Rosner. Jacek Malczewski, who resided in Vienna from the beginning of World War I until 1916, painted, among other things, a portrait of Pochwalski against the background of the war.

In the summer of 1919, Kazimierz Pochwalski returned to Krakow permanently. Between 1926 and 1936, he made many journeys in his country and to Vienna for several purposes. He also visited his children, who lived in different cities. ${ }^{11)}$ Enjoying good health, he painted: "almost to the last moment of life - for up to 12 days before his death" (according to his son R. Joseph Nicholas). He died of pneumonia during the war in 1940, at the age of eighty-five. ${ }^{12)}$

6) http://www.myheritage.pl/person-43000342_141082781_141082781/kazimierzteofil-pochwalski

7) http://www.myheritage.pl/person-43000342_141082781_141082781/ kazimierzteofil-pochwalski

8) http://www.pochwalski.edu.pl/readarticle.php?article_id=15

9) http://www.pochwalski.edu.pl/readarticle.php?article_id=15

10) http://www.henryk-sienkiewicz.eu/index.php?id =postacie\&m= menu biografia\&akcja $=$ pokaz\&litera $=\mathrm{P}$

11) http://www.henryk-sienkiewicz.eu/index.php?id=postacie\&m=menubiografia\&a $\mathrm{kcja}=$ pokaz\&litera $=\mathrm{P}$

http://www.myheritage.pl/person-43000342_141082781141082781/kazimierz-teofilpochwalski

12) http://www.pochwalski.edu.pl/readarticle.php?article_id=15 


\section{THE EASTERN TRAVELS OF KAZIMIERZ POCHWALSKI}

The first trip to Turkey, Greece and Italy, started in October 1884 and took four months. During the trip, Kazimierz Pochwalski was accompanied by the writer Henryk Sienkiewicz and journalist Antoni Zaleski (Fig. 1). The outward journey took in Chernivtsi, Bucharest, Danube, Varna and Istanbul; while his return path covered Piraeus, Athens and Rome. During the Eastern trip in 1891, with Count Andrzej Potocki, the arrival route was as follow: Vienna, Trieste, Alexandria and Cairo. ${ }^{13)}$

During the first trip to the East, in Anadolukavağ 1 , at the entrance to the Bosphorus, they had remained in quarantine for ten days in a Russian ship named Olga. Anadolukavağ looks like a small village set between the rocks (Fig.2). During this quarantine in October, the weather was windy and rainy, and the sea was rough. Henryk Sienkiewicz had just finished the second book of his Trilogy; but had not got the attention he had hoped for and his beloved wife had succumbed to tuberculosis. It appears he had found solace in this Eastern trip with his friends Pochwalski and Zaleski. The third volume of the Trilogy would be on the subject of the Ottoman-Polish war of the 17th century. ${ }^{14)}$

Henryk Groppler, whom they visited in Istanbul, was the cousin of Jan Matejko, who had taught Pochwalski. Henryk Groppler's house was on the shores of the Bosphorus, in the district of Bebek, and was often visited by Poles who were living or visiting to Istanbul.

The wealthiest and most prominent Pole in Istanbul at that time was Henry Groppler - the owner of great marble and borax mines, who had been resident in the city for 35 years. According to the recollections of a handful of Poles, Groppler owned a guesthouse which bore the unofficial name of 'Polish Consulate'. It is thought that Groppler had come to Istanbul in the eighteen-sixties, and along with his friend Camille Desmazures, who was a French engineer, they were the pioneers who discovered and processed borax in Turkey. Groppler traded borax and marble and owned nine ships. He also provided materials for the new or renovated buildings in the Ottoman State. He acquired the operating rights of a mine near Bandirma from the

13) http://www.myheritage.pl/person-43000342_141082781_141082781/kazimierzteofil-pochwalski

14) $\mathrm{http} / / /$ www.henryk-sienkiewicz.eu/index.php? id=postacie\&m=menu_biografia\& akcja $=$ pokaz\&litera $=\mathrm{Z}$ 
Sultan and lived a wealthy life in Bebek, Istanbul. In 1872, Matejko and his wife came to Istanbul to visit the Groppler family. Groppler's wife was from an intellectual family and she was a composer and a pianist in her own right as well. Their home was visited by, among others: Adam Karol Brzozowski, Jerome (the brother of Napoleon), Jan Matejko (with his wife) Jan Styka and Henryk Sienkiewicz. ${ }^{15)}$

The second Eastern journey took place in February, 1891. Pochwalski, who had been invited by Andrzej Potocki, went to Egypt with him and his wife Maria Tyszkiewicz, Zdzislaw Tarnowski and Branicki. They went through Vienna and Trieste, by ship to Alexandria, then arrived in Cairo, where they sailed up the Nile. On the way back to Alexandria, Pochwalski met Sienkiewicz, and together they went to Krakow. ${ }^{16)}$

\section{TH CENTURY ISTANBUL AND ORIENTALISM}

By the end of the 18th century, Turkish fashion in Europe (Turquerie) had ended, and been replaced by a more romantic interest of the East, known as Orientalism. In truth, the West first came into full contact with the East in a real sense, in the 19th century: Victor Hugo wrote Les Orientales in 1829, Eugene Delacroix's visit to the East was in 1832, Napoleon Bonaparte's expedition to Egypt was in 1798 - and the book named Description de l'Egypte was printed between 1809-1822 in 24 volumes. The French occupied Algeria in 1830, the Greek War of Independence happened between 1821 and 1830 and the Crimean War was fought between 1854 and 1855. During this period, a great many excavations were undertaken and relics transported to European museums. Antoine Galland's French translation of the Arabian Nights, literary works, travelogues, memoirs, costume albums in particular, the increasing numbers of travel books, Universal Exhibitions opening in Europe - all increased the interest in the East. Following the increase in the level of income of the nobility and the improvements in conditions of transportation, tours were organized to the East. All of these helped the 'imagined East' turn itself into a real world.

Western artists who had confined themselves to highlighting only certain aspects of the Ottoman world in earlier centuries, now produced works documenting this culture's customs and traditions, daily lifestyle, ethnic

\footnotetext{
15) http://poloniawstambule.com/tag/antoni-zaleski/

16) http://www.pochwalski.edu.pl/readarticle.php?article_id=15
} 
types, clothing and architecture. Istanbul, as well as being the capital of the Ottoman Empire, with its natural beauty and historical monuments, and its Eastern and cosmopolitan life, was the city that attracted the greatest interest of European artists. Between 1850 and 1900, the number of foreign artists who came to Istanbul significantly increased compared with previous times. ${ }^{17)}$ Some Orientalist artists who came to Turkey in the period of Sultan Abdulmecid include: Carl Haag, Adolf Schreyer, Germain Fabius Brest, Jean Baptiste Huysmans, Adolphe Yvon, Horace Vernet, Felix Ziem, Richard Dadd, William Holman Hunt, John Frederick Lewis and Edward Lear. During this period, Amedeo Preziosi and Joseph Schranz also came and settled in Istanbul. The interest shown in the art of the Abdulmecid period continued to increase during the period of Sultan Abdulaziz, a sultan who: travelled abroad to visit some exhibitions, was a painter and composer, supported various kinds of arts, was the first sultan to have his statue made and create a collection of pictures in the palace - the opening of his first painting exhibitions in Turkey occurred during his reign. Among the Orientalist artists who came to Turkey in this period were: Rudolf Ernst, Walter Charles Horsley, Frederick Leighton, Alberto Pasini, Jean Leon Gérome, and Charles Müller. The long reign of Abdulhamid II was a period where the results of the breakthroughs in the field of art were seen. The establishment of the Academy of Fine Arts and the opening of the Istanbul halls, played an important role in the revival of city's artistic scene. In this period of the revival of Orientalism in Europe, the number of European painters visiting Turkey is noteworthy: Albert Aublet, Edouard Debat-Ponsan, Paul Leroy, Emile Bernard, Frank Brangwyn, Edwin Lord Weeks, Marius Bauer, John Singer Sargent and other artists of note. ${ }^{18)}$

After the second half of the 19th century, Orientalist paintings became more realistic. ${ }^{19)}$ Foreign visitors who came to Istanbul chose to buy travel memorabilia depicting various professions such as: artists, merchants, street vendors, soldiers and so on. Various ethnic groups living in the Ottoman Empire were also depicted: Turks, Albanians, Greeks, Armenians and others. ${ }^{20)}$ The East, as well as possessing a rich visual quality, diversity and difference from the West, also offered a variety of opportunities to painters due to its climate and geography. Therefore, Orientalist artists made numerous sketches

\footnotetext{
17) Germaner (1989: 77)

18) Germaner (1989: 84).

19) İnankur (1993: 77).

20) İnankur (1993: 80).
} 
and watercolours during trips to the East, and after returning to their countries, took advantage of them to produce paintings. They also used all kinds of materials brought from the East.

\section{TH CENTURY POLISH PAINTING AND ORIENTALISM}

In the 19th century, Polish art passed through successive stages of different artistic trends, each influencing the other, of which two were the most important: Romanticism and Historicism. ${ }^{21)}$ Yet Polish 19th century painting was not as concentrated on exoticism and eroticism as Western European painting. Furthermore, the trend of Orientalism was represented in a rather scanty fashion. The Polish artists who visited the Near East and North Africa, do not return in later paintings to these motifs in later paintings. ${ }^{22}$ Among artists who have visited or who have stayed in the Ottoman Empire were: Stanislaw Chlebowski, Tadeusz Ajdukiewicz, Adam Styka, Wacław Pawliszak, Antoni Piotrowski, Kazimierz Pochwalski, Jan Ciaglinski ${ }^{23)}$ and others. ${ }^{24)}$

\section{POCHWALSKI'S SKETCHBOOK}

For each artist, the sketches of Orientalist painters are as important as their canvas paintings. They show the development of the style of the artist, and these drawings are also important documents of Eastern life. Pochwalski's drawings focus on the subject of people and clothing in various detailed sketches. His sketchbook has been placed in the Jagiellonian Library, Krakow, and contains seventy-eight sketches. When we look at these sketches, which have been drawn either in watercolour or charcoal pencil, we can see that some of them have been done quickly and others with detail. Sometimes the details are handled separately, while sometimes they appear in a composition. When examined as a whole, we see mainly figurative sketches. Pochwalski could be interpreted as being a portrait painter. In addition to full-sized figures, there are some examples depicting only the head and feet of the model. Some of these figures have facial expressions. In general, the clothes of the figures are highlighted. A variety of Eastern or ethnic stereotypes are

\footnotetext{
21) Krzysztofowicz-Kozakowska (2003: 10).

22) Majda (1995: 440, 441).

23) Writer's addition.

24) Majda (1995: 441).
} 
depicted. Besides compositions featuring people, pictures of boats, ships and their details were the second main subject of the painter. Most of them are drawings of people on the deck of a boat. Apart from these subjects, we can also find landscapes with houses. On some pages, details unrelated to one another have been shown together.

In one of the early pages of the sketchbook (Fig.1) Pochwalski pictured himself on the deck of a boat with Henryk Sienkiewicz and Anton Zaleski. Fifty-six years after this trip, Pochwalski, who had made self-portraits throughout his life, depicted himself with Henryk Sienkiewicz in an oil painting (Fig.3). While so doing, he drew on his earlier portraits of Sienkiewicz and some photographs. After so many years, his fondness for the memories of this trip is remarkable. In the painting, both men - Sienkiewicz and Pochwalski - are captured to the waist. The writer sits facing the viewer with her head turned slightly to the right. One hand is placed on the railing of the ship, the other on her knees. To his right sits Pochwalski, visible in profile. The painter has turned his face to the writer, as if in conversation. His left hand is lifted slightly upward. Sienkiewicz is wearing a grey-blue jacket and white shirt with collar. On his head is a grey 'Scotch' cap. Pochwalski is wearing a brown colour coat. The background image is the sea and outline of the shore with buildings. ${ }^{25}$

\section{CONCLUSION: POCHWALSKI AND HIS SKETCHES IN ORIENTALISM}

Throughout the 19th century, an ever greater number of Orientalist painters visited the East. In the middle of the century, hundreds of European painters travelled to Eastern countries. Towards the end of this period, Polish painter Kazimierz Pochwalski visited the East twice, where he made sketches with notes. However, he did not later use these sketches in his oil paintings, which was the general practice for this type of artist. Nonetheless, Pochwalski's Eastern sketches show similarities to those of other Orientalist painters, in terms of perspectives and common approaches to the issues of the East. This points to the influence of various teachers and colleagues and also gives us the idea that Pochwalski followed the fashion of the period, travelling to the East, and drawing pictures based on his own observations. Like other Ori-

25) http://mnki.pl/pl/obiekt_tygodnia/2013/henryk_sienkiewicz_i_kazimierz_pochwalski_na_statku/ 
entalist painters of the period, he carefully observed, recorded and produced drawings of value (Figs. 4-5). If we look at the paintings, and especially the sketches made during the 19th century, we can observe that the artists mainly dealt with figurative compositions, landscapes, the interior and exterior of buildings and details of a variety of objects, especially clothing. The same features appear in the drawings.

Pochwalski grew up in a family of artists, who had many connections and friends among whom were also Orientalists. Jan Matejko was Pochwalski's mentor, and one of Matejko's students was Pochwalski's teacher as well. Leon Bonnat, who was his teacher in Paris, was a friend of the Orientalist painter, Jean Leon Gérome. We know that, when Pochwalski came to Istanbul, he visited the house of Henryk Groppler, who was the cousin of Matejko. All Polish citizens in Istanbul, particularly painters such as Stanislaw Chlebowski, visited Groppler's house. One further painter, Chlebowski, came to Istanbul on the invitation of Sultan Abdulaziz and was the court painter for twelve years. Chlebowski studied art in the atelier of the famous Orientalist painter Jean Leon Gérome, at Ecole des Beaux-Arts ${ }^{26}$. Jacek Malczewski was a student of Jan Matejko and also a friend of Kazimierz Pochwalski, who went to the East at about the same period. Apart from the influence of other artists, Pochwalski was probably aware of the Orientalist literature, clothing albums, travel books and guides. For example, he could have seen the diaries of Edward Raczynski, recording his trip to Turkey in 1814. Pochwalski's book of sketches from his first trip to the East, which is the subject of our paper, is remarkable for the reasons described above. There is very likely to be a book for the second journey, but so far no definite information has come to light regarding this matter.

\section{BIBLIOGRAPHY}

Blak (2001) $=$ Halina Blak, Barbara Malkiewicz, Elzbieta Wojtalowa. Polish Painting of the 19th Century, The National Museum in Cracow, Cracow 2001.

Germaner (1989) = Semra Germaner, Zeynep İnankur. Oryantalizm ve Türkiye (Orientalism and Turkey), Türk Kültürüne Hizmet Vakfı Sanat Yayınları (Turkish Culture Foundation Art Publishings), İstanbul 1989.

İnankur (1993) = Zeynep İnankur. "19.yüzyılın ikinci yarısında İstanbul'a Gelen Batılı Sanatçlar" (Western Painters who came to Istanbul in the second half of the 19th

26) Blak (2001: 49) 
Century), Osman Hamdi Bey ve Dönemi (Osman Hamdi Bey and his Period), Tarih Vakfı Yurt Yayınları (History Foundation Publishings), İstanbul 1993: 75-82.

Krzysztofowicz-Kozakowska (2003) = Stefania Krzysztofowicz-Kozakowska. Polish Paintings in Collections Abroad, Krakow 2003.

Majda (1995) = Tadeusz Majda. "Polish Artists in the Ottoman Empire up to the 19th Century”, 9th International Congress of Turkish Art, (İstanbul 23-27 September 1991), vol.2, Ankara 1995: 439-442.

Micke-Broniarek (2008) = Ewa Micke-Broniarek. Polish Painting - Realism and Naturalism, Warsaw 2008.

Stewart (1971) = Stewart, Jean (ed. \& trans.), Eugène Delacroix. Selected Letters 1813-1863, New York, 1971: 192.

http://www.henryk-sienkiewicz.eu/index.php?id=postacie\&m=menu_biografia\&akcja $=$ pokaz \&litera $=\mathrm{P}$

http://www.henryk-sienkiewicz.eu/index.php?id=postacie\&m=menu_biografia\&akcja $=$ pokaz \&litera $=\mathrm{Z}$

http://mnki.pl/pl/obiekt_tygodnia/2013/henryk_sienkiewicz_i_kazimierz_pochwalski_na_statku/

http://www.myheritage.pl/person-43000342_141082781_141082781/kazimierz-teofilpochwalski

http://www.pochwalski.edu.pl/readarticle.php?article_id=15

http://www.pochwalski.edu.pl/readarticle.php?article_id=51

http://poloniawstambule.com/tag/antoni-zaleski/ 
[210]

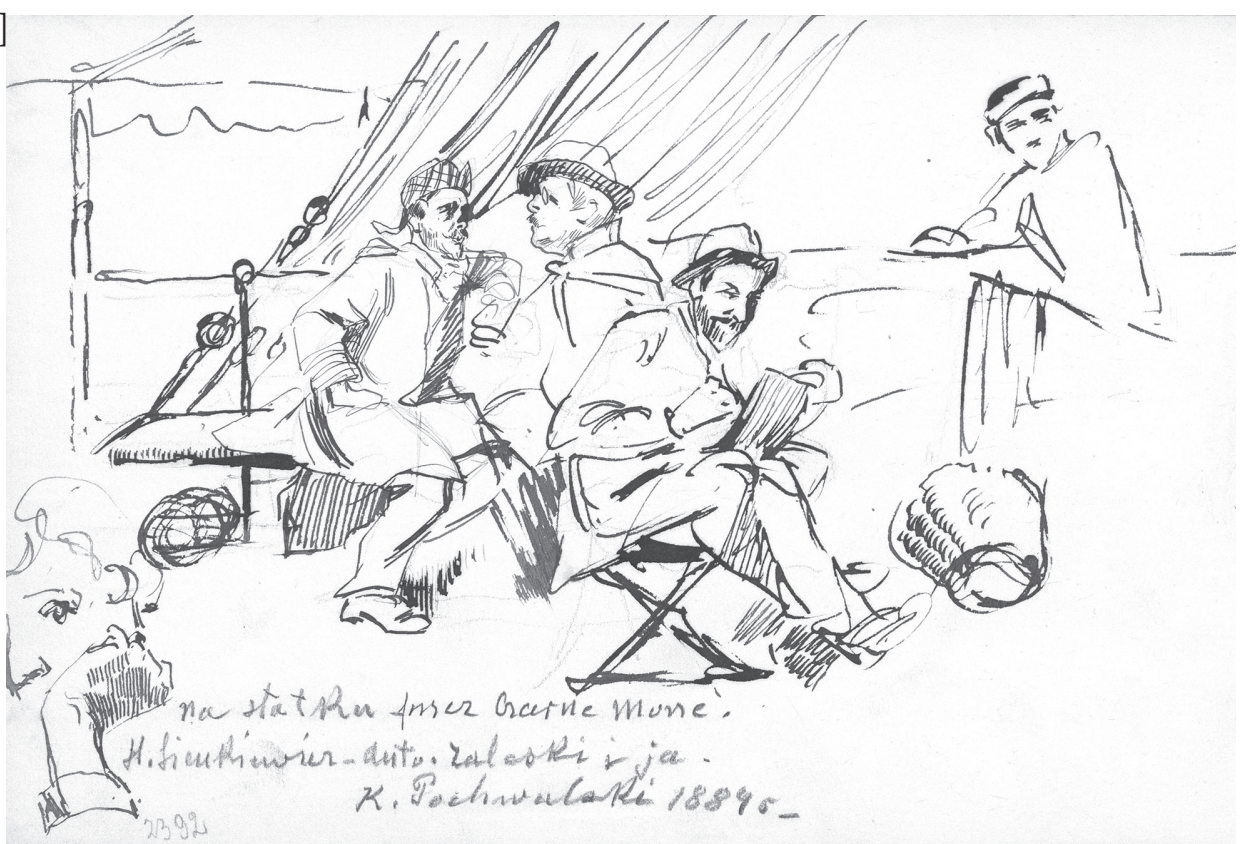

Fig. 1. K. Pochwalski: "On the ship on the Black Sea, Sienkiewicz, Zaleski and myself"from Pochwalski's sketchbook (with permission of the Jagiellonian Library, Krakow)

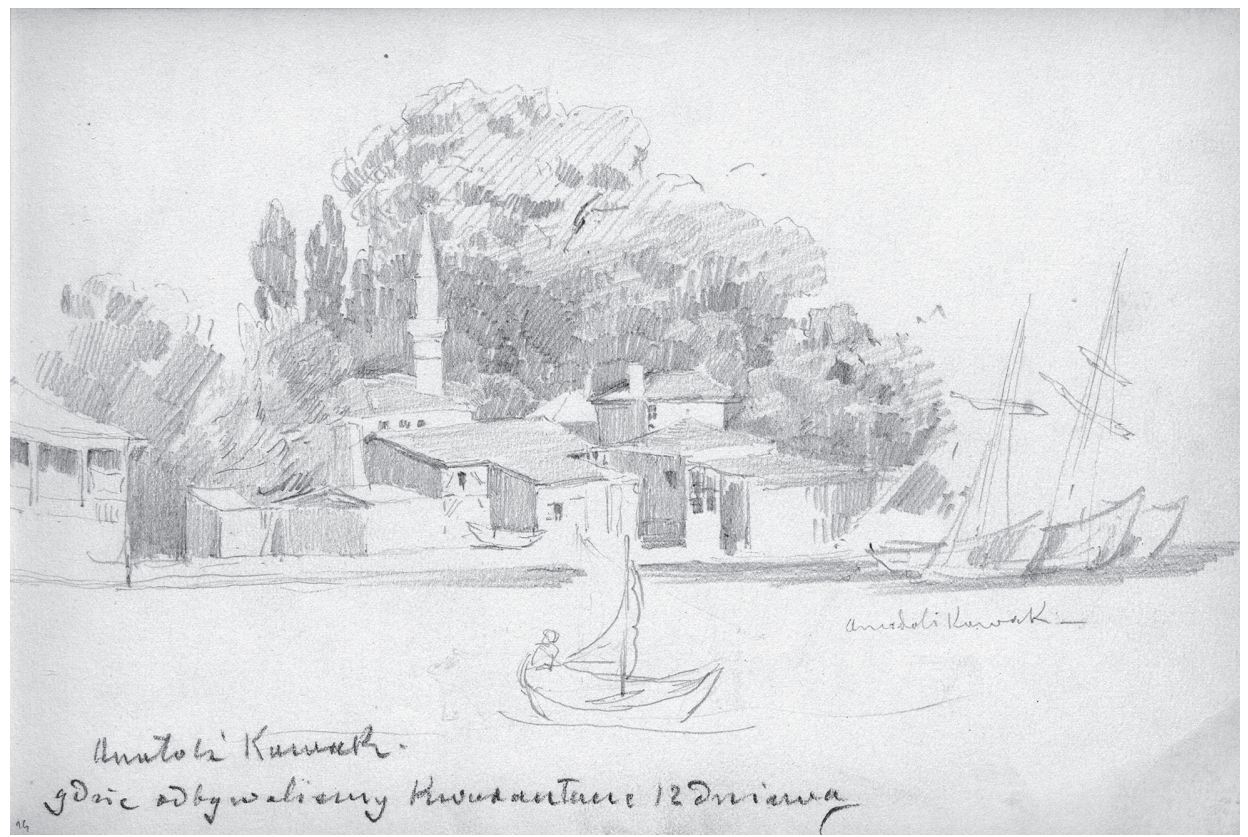

Fig. 2. K. Pochwalski: "Anadolu kavak, where we spent 12 days in quarantine"- from Pochwalski's sketchbook (with permission of the Jagiellonian Library, Krakow) 


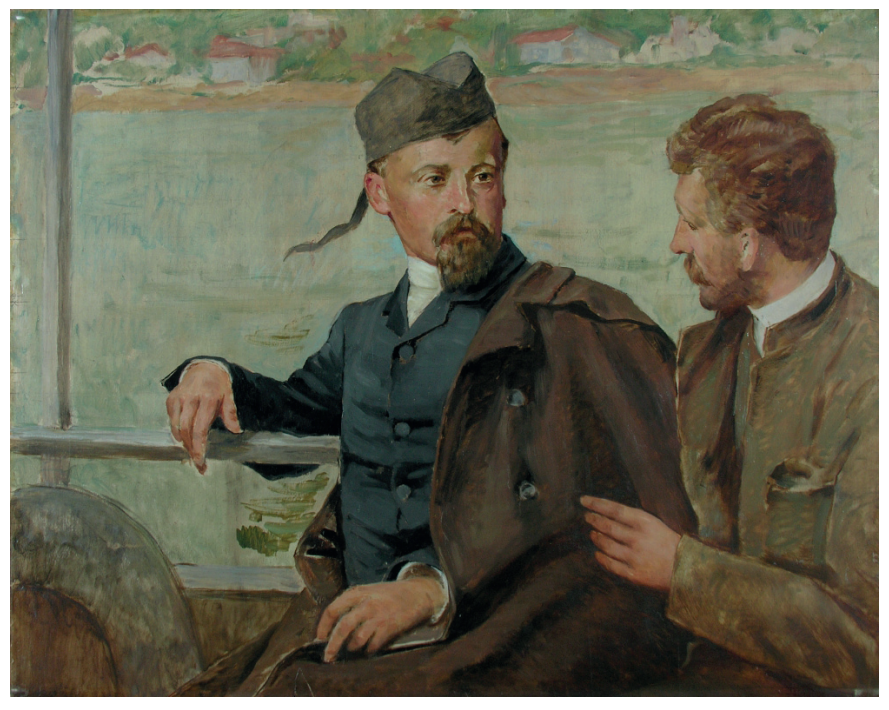

Fig. 3. K. Pochwalski: Henryk Sienkiewicz and Kazimierz Pochwalski on ship, circa 1940, Oil on plywood, $102 \times 81 \mathrm{~cm}$ (http://mnki.pl/pl/ obiekt_tygodnia/2013/ henryk_sienkiewicz_i_ kazimierz_pochwalski_na_statku/)
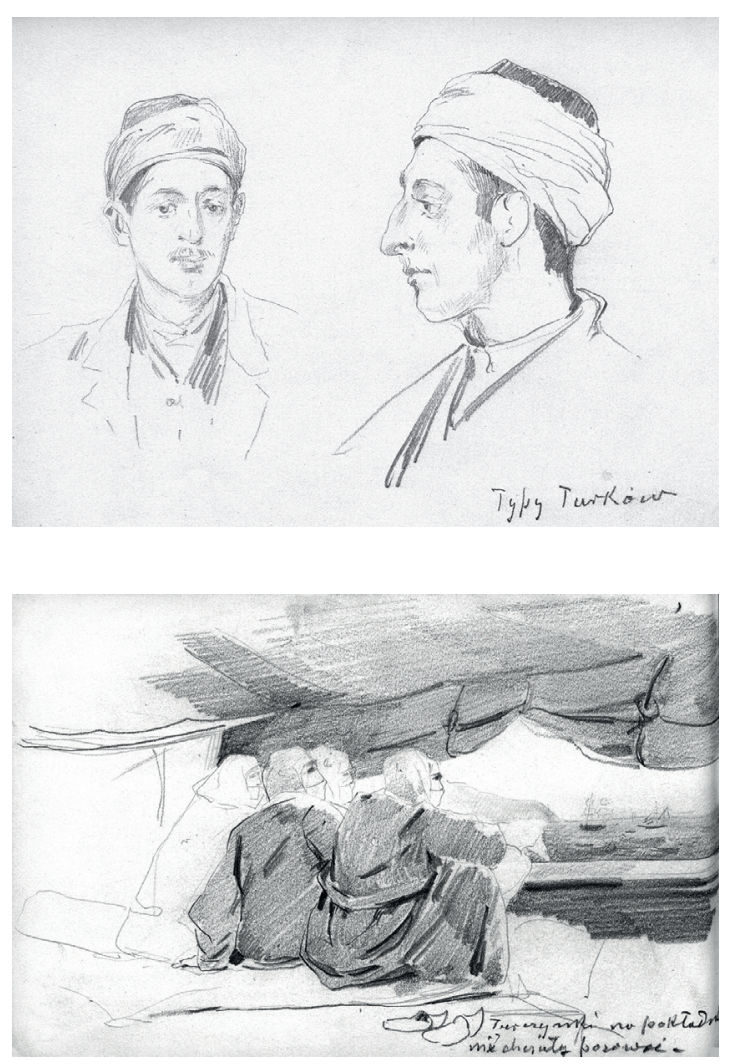

Fig. 4. K. Pochwalski: "Turk" from Pochwalski's sketchbook (with permission of the Jagiellonian Library, Krakow)

Fig. 5. K. Pochwalski: "Turkish woman on board, they didn't want to be drawn" - from Pochwalski's sketchbook (with permission of the Jagiellonian Library, Krakow) 